Arab World English Journal (AWEJ) 2 ${ }^{\text {nd }}$ Special Issue on Covid 19 Challenges January $2022 \quad$ Pp.492- 503 DOI: https://dx.doi.org/10.24093/awej/covid2.33

\title{
Learning in the Algerian Context during the Pandemic: Is it online or offline?
}

\author{
Nadia Ghounane \\ Department of English Language and Literature \\ Saida University, Algeria \\ Email: nadoushben@ymail.com
}

Received: 12/25/2021

Accepted: 1/18/2022

Published:1/24/2022

\section{Abstract}

The spread of the Covid-19 leads academic institutions all over the world to shift to online mode through educational platforms like Moodle, blackboard, and Teams or towards the informal ways of learning through YouTube and Social Networking Sites, mainly Facebook or through the inclusion of some apps like Zoom and Google meet. Algerian Universities also hasten to replace face-to-face with online mode. However, there are many challenges, among which is the absence of interaction between teachers and students since most of the lectures are posted in an asynchronous online mode. The study attempts to answer the main research question: Which learning mode is used in Algeria during the pandemic? The current paper tends to give an indepth look at the teaching and learning situation of English in the Algerian context during the pandemic. It also sheds light on the nature of the learning mode. The researcher conducted the study with four universities from different regions in Algeria. Data were collected quantitati vely and qualitatively using a questionnaire, an interview, and observation. Findings revealed that most universities use asynchronous online mode in learning. The analysis also demonstrated that the asynchronous mode affects EFL students' motivation towards e-learning and raises their technostress since they have not developed e-learning readiness yet.

Keywords: Algerian EFL learners, Covid-19 pandemic, e-readiness, offline learning, online learning, technostress

Cite as: Ghounane, N. (2022). Learning in the Algerian Context during the Pandemic: Is it online or offline? Arab World English Journal (AWEJ) $2^{\text {nd }}$ Special Issue on Covid 19 Challenges (2) 492- 503. DOI: https://dx.doi.org/10.24093/awej/covid2.33 
Arab World English Journal (AWEJ) 2nd Special Issue on Covid 19 Challenges January 2022

\section{Introduction}

Teachers and students can access online sources for educational purposes through the net. The dawn of technology and its gifts help students to contact their teachers out of class in a virtual mode either through the use of social networking sides like Facebook, Twitter, or Whatsapp, or emails or through synchronous mode that provides a virtual environment by using educational platforms like Moodle, Blackboard, or Teams. These educational platforms are supported by informal modes like Zoom, Google Meet, Jitsi apps, etc. Through the dawn of these apps and learning platforms, students' perceptions and learning habits have changed since technology can allow both teachers and students to learn without barriers.

Despite the extensive use of technology in education in the last years, mainly during the Covid-19 pandemic era, there are still many raised issues, including the lack of interaction and communication between the teacher and the learner, which affects students' involvement in learning the language. Other issues, which technology cannot substitute for the learning process, are the role of the teachers' physical presence in the classroom and face-to-face interaction. These points are important parameters in enhancing students' motivation and achievement.

As the Covid-19 has spread, all academic institutions worldwide hasten to replace faceto-face learning mode with online learning. Reshaping teaching and learning according to online demands has raised many issues. Countries face many difficulties in shifting to online learning, mainly in countries where the e-learning mode is still in its infancy. Although e-learning has been introduced to some Algerian universities years ago, teachers and students are still facing what we can call technophobia in getting involved in an e-learning setting since guiding and motivating students to learn online through educational platforms and applications are still absent in the Algerian context. What is posted on some educational platforms is not online learning. In implementing online learning, the teacher should create a virtual classroom to promote face-toface learning in virtual settings. Teachers tend to post just handouts and videos for students while interaction is absent. Even how these lectures are prepared needs to be reconsidered. The present study aims to shed light on the teaching/ learning situation in the Algerian context during the pandemic. It explores students' learning experiences in different modes to cast some light on the mode used during the pandemic. In this regard, the main research question piloting the study is: Which learning mode was used in the Algerian context during the Covid 19 pandemic? Is it the offline or the online mode? The researcher supported the research questions with three pivotal research questions:

- What are the learning measures taken by the Algerian universities during the pandemic?

- Does the offline mode affect teachers' and students' readiness for online learning?

- What are the teachers' and students' perceptions towards the online mode? 
The researcher aimed to provide an in-depth look at the teaching and learning process during the pandemic, hoping that it may find solutions or provide background for other researchers to explore some emerging problems after the sudden shift from face-to-face to online mode. It is an original contribution since the scarcity of studies on this topic necessitates further investigations.

\section{Literature Review Section \\ Online vs Offline Learning}

Online and offline modes are essential concepts in education. The offline mode refers to face-to-face learning or the traditional mode of learning. Classroom environment, classroom, teachers' and students' physical presence, and interaction are essential features in the conventional mode of learning. Online learning is not new, but demands on its use have increased in education during the pandemic. Online learning helps in the continuation of education during the pandemic. It has replaced face-to-face learning during the breakdown. Both online and offline modes have their features that can be summarized in the following:

Table 1. Online vs. offline learning

\begin{tabular}{|c|c|c|}
\hline Particulars & Online education & Offline education \\
\hline Method of teaching & $\begin{array}{l}\text { Digitalized tools and } \\
\text { methods of teaching }\end{array}$ & $\begin{array}{l}\text { Traditional tools and } \\
\text { methods of teaching }\end{array}$ \\
\hline Cost and time & $\begin{array}{l}\text { Coast-effective and time- } \\
\text { saving }\end{array}$ & $\begin{array}{l}\text { More expensive than online } \\
\text { education and consumes } \\
\text { more time }\end{array}$ \\
\hline Location & Virtual classrooms & Physical classrooms \\
\hline Flexibility & $\begin{array}{l}\text { Online classes have a flexible } \\
\text { schedule }\end{array}$ & $\begin{array}{l}\text { Offline classes have a fixed } \\
\text { and strict schedule }\end{array}$ \\
\hline Communication & $\begin{array}{lr}\begin{array}{l}\text { Communication } \\
\text { collaboration } \\
\text { digitally }\end{array} & \begin{array}{r}\text { and } \\
\text { happen }\end{array} \\
\end{array}$ & $\begin{array}{l}\text { Communication } \\
\text { collaborations happen face- } \\
\text { to-face }\end{array}$ \\
\hline Type of approach & $\begin{array}{ll}\text { Facilitation } & \text { and } \\
\text { asynchronous approach } & \\
\end{array}$ & $\begin{array}{ll}\text { Instructional } & \text { and } \\
\text { synchronous approach } & \\
\end{array}$ \\
\hline Pace of learning & $\begin{array}{l}\text { Students largely determine } \\
\text { the pace of learning }\end{array}$ & $\begin{array}{l}\text { Teachers largely determine } \\
\text { the pace of learning }\end{array}$ \\
\hline Level of commitment & $\begin{array}{l}\text { Students are less likely to } \\
\text { remain serious and } \\
\text { committed to their studies }\end{array}$ & $\begin{array}{l}\text { Students remain more serious } \\
\text { and committed to their } \\
\text { studies }\end{array}$ \\
\hline
\end{tabular}

Note 1. Adopted from Team Leverage Edu (2021, para. 2) 
Table one demonstrates that the online mode differs from the offline because it changes the learning process and makes it more flexible. Students can develop their self-directed learning, and self-discipline through the online mode.

It is impossible to replace traditional learning with online learning in the view of some researchers. Dixwas and Dey (2020) maintained that many challenges are facing the implementation of online learning. These researchers pointed that that "the biggest challenge in the case of online education is the self-discipline, patience and sincerity during the learning process of the learners" (p. 4). Interaction and promoting an appropriate classroom environment are limited in online learning (Dixwas \& Dey, 2020).

\section{Teachers' and Students' Perceptions towards Online Learning}

It is essential to talk about students' perceptions since it is a vital component in the learning process. Muthuprasad, Aiswarya, Aditya, and Girish (2021) claimed that it is crucial to design appropriate online content to motivate students. They claimed that "it is very important to consider the preferences and perceptions of learners while designing the online courses to make the learning effective and productive" (p. 2). Indeed, students' perceptions and preferences are linked to readiness. Warner et al. (1998) maintained that e-readiness is important in online learning. They described it to three components, mainly:

The preference of student's for the way of delivery as opposed to face-to-face classroom instruction, (2) student's confidence in utilizing the electronic communication for learning which includes competence and trust in the use of the Internet and computerbased communication; and (3) capability to engage in autonomous learning. (cited in Muthuprasad, et al., 2021, p. 2)

To implement online learning, institutions need to study and plan according to teachers' and students' perceptions. To introduce e-content without studying its effectiveness may affect students' perceptions.

Preparing an appropriate e-content may receive good perceptions and help students to develop their e-readiness. However, instructors have to consider issues linked to how students perceive the curriculum and whether the students can work with the provided materials and receive quick feedback from their teachers since studies showed that there is a problem in terms of feedback i.e., teachers are lazy when it comes to giving an e-feedback to students. Hence, "successfully implementing online learning into the curriculum requires a well-thought-out strategy and a more active approach" (Baczek, et al., 2021, p. 5). 
Arab World English Journal (AWEJ) 2nd Special Issue on Covid 19 Challenges January 2022

\section{Teaching in Algeria during the Pandemic}

Algeria, like many other countries, responded to the pandemic situation and planned some strategies to save the teaching/learning situation. According to Chelghoum and Chelghoum (2020), the pandemic forced the Algerian policymakers to provide instructions during the lockdown. Education was the first domain where institutions and universities shifted to online learning. Hence, schools and universities were forced to use technology and "set online teaching plans using different tools and platforms" (Dignan, 2020, cited in Chelghoum \& Ghelghoum, 2020, p. 125).

Teachers in the Algerian context tend to use different tools and platforms to promote online teaching during the pandemic. According to Ghounane (2020), teachers hasten to upload lectures and videos on learning platforms like Moodle and Teams, while a small minority tend to host live classes through Facebook and other applications, mainly Google Meet and Zoom. When it comes to the use of Social Networking Sites (SNSs), Algerian teachers showed negative attitudes towards Facebook. According to Ghounane (2021), Algerian teachers regarded SNSs as informal ways of learning, although settings like Facebook help both teachers and students at the international level to promote education during the pandemic. Daniel (2020) also claimed that the success of online learning in the educational setting in any country depends mainly on the teachers' and learners' attitudes and perceptions towards the online mode.

Implementing online learning in the Algerian context faces many obstacles, among which the students' attitudes towards online learning. This attitude is directed by many constraints, among which lack of training on how to use educational platforms, net problems, and their low social status. Almaiah, Al-Khasawneh and Alrhunibat (2020) highlighted that students "have difficulties in access and use of digital technologies, where not all of them have computers, smartphones or Internet at home. Besides, ineffective feedback is noticeable because almost all remote learning tools are asynchronous" (cited in Benkhider \& Kherbachi, 2020, p. 340). Other constraints can be limited to the non-mastery of the ITC tools by students and teachers, as well as "the low internet speeds, which prevents students from downloading their online courses. Also, it is not all students have the necessary device such as computers and smartphones to pursue remote learning “ (Derradj, 2020, cited in Benkhider \& Kherbachi, 2020, p. 341).

The teaching and learning process in the Algerian context does not differ from other countries, mainly in Africa. Most countries struggle to implement online learning and replace face-to-face learning due to the Covid-19 situation. Universities and institutions hasten to implement e-learning without giving much importance to training teachers and students on how to use different techno apps and educational platforms. Another critical issue is that not all Algerian universities implement online learning through live courses (synchronous mode) but rather through asynchronous online learning. This fact has an impact on students' perceptions 
Arab World English Journal (AWEJ) 2nd Special Issue on Covid 19 Challenges January 2022

and attitudes towards e-learning. Hence, the current study aims to shed light on the teachinglearning situation in the Algerian context during the pandemic.

\section{Methods}

The study attempts to explore the teaching mode in Algeria during the pandemic. It also investigates the type of online learning used in the Algerian context. This study was conducted between October and December 2021. During this period, most teachers posted their lectures through the Moodle platform. The researcher collected data quantitatively and qualitatively. The research tools consisted of an online questionnaire, an interview, and observation.

\section{Participants}

The researcher selected the participants from four universities in Algeria, mainly Tlemcen, Saida, Ouargla, and Batna. The researcher followed non-random selection. The questionnaire was distributed online through Google forms to 51 teachers, while the interview was conducted with 23 teachers.

In terms of their teaching experiences, these teachers have been teaching for six to 25 years. About $83 \%$ of them used online learning to support face-to-face learning during the Covid-19, while a small minority declared that they employed online learning before the pandemic. Seventy-eight percent of the teachers claimed that they received training on how to use some educational platforms, mainly Moodle and Teams. They added that they were given just some guidelines on how to use these platforms and not on how to deliver an online course and assignment.

Another questionnaire was posted online to students on their groups of Facebook. This questionnaire aimed to test their perceptions of online and offline modes. One hundred and five students from different specialties and levels answered and emailed the questionnaire.

\section{Research Instruments}

\section{Teachers' and Students' Questionnaires}

The first section of the questionnaires was designed to gather information about teachers' and students' personal information like age, gender, teaching, and learning experiences. The second section attempted to answer the main research question "Which learning mode was used in the Algerian context during the pandemic? Is it online or offline?" The third section aimed to find an answer to the second research, "Does the offline mode affect teachers' and students' readiness for online learning?" while the fourth section answered the last question.

\section{Teachers' Interview}

The researcher interviewed 23 teachers from the four mentioned universities. The teachers belonged to different specialities. Most of them recorded their interviews and sent them 
Arab World English Journal (AWEJ) 2nd Special Issue on Covid 19 Challenges January 2022

via mails. The interview contained six questions. The questions addressed the mode of teaching used during the pandemic, how the lectures were delivered, and their perceptions towards both modes.

\section{Observation}

The observation took three weeks during the first semester of the last year. The researcher consulted two educational platforms, mainly Moodle and Teams. The ministry of higher education introduced Moodle as an educational platform, and institutions tend to train teachers on its use. The researcher accessed, mainly the Moodle platform since universities provide access to all students and teachers at the beginning of the semester due to many reasons, mainly, students' enrolment and technical problems.

\section{Findings}

\section{Teachers' and Students' Questionnaires}

The researcher selected the most crucial questions linked to the study research questions. Which teaching mode was used in the Algerian context during the pandemic? Is it offline or online?

Table 1. Teaching mode in the Algerian context during the pandemic

\begin{tabular}{|l|l|}
\hline Teaching mode & Percentage \\
\hline Offline & $39 \%$ \\
\hline Online & $61 \%$ \\
\hline
\end{tabular}

Table one indicates that $61 \%$ of the lectures were delivered online, while $39 \%$ of them were done through face-to-face mode since students have to be present for traditional classes for four to seven weeks in the semester.

Which type of online learning was used?

Table 2. Types of online learning

\begin{tabular}{|l|l|}
\hline Types of online learning & Percentage \\
\hline Asynchronous Online Courses & $73 \%$ \\
\hline Synchronous Online Courses & $20 \%$ \\
\hline Hybrid Courses & $07 \%$ \\
\hline
\end{tabular}

Table two shows the type of online learning used during the pandemic. Seventy-three percent of the teachers highlighted that they tend to use the asynchronous online mode. They tend to post their lectures in the form of handouts, videos, homework, and assignments, while $20 \%$ of them follow synchronous mode. 
Arab World English Journal (AWEJ) 2nd Special Issue on Covid 19 Challenges January 2022

Did the reduced sessions of offline mode affect the learning process?

Table 3. The impact of the reduced offline sessions on the learning process

\begin{tabular}{|l|l|}
\hline Answer & Percentage \\
\hline Yes & $93 \%$ \\
\hline No & $7 \%$ \\
\hline
\end{tabular}

Table three indicates that reducing the number of sessions in face-to-face learning has affected the learning process. Most of the informants claimed that the Covid-19 pandemic has a profound impact on the teaching/learning situation in Algeria. At the same time, 7\% of the teachers stated that the institutions supported the reduced sessions by virtual courses.

\section{Interview}

The interview contained six essential questions that may answer the research questions. The researcher selected the most important ones.

\section{First Question}

What are the strategies implemented by the Algerian Universities to promote learning during the pandemic?

Most of the informants claimed that all Algerian universities shifted to the use of asynchronous online mode through posting handouts and videos on Moodle. They added that this type of online mode had affected the learning process since there is no interaction between the teacher and his/her students. The second reason is that most students developed negative attitudes towards asynchronous online courses since teachers are not trained to prepare an online lecture and assignment.

Second Question: Did the combination of both modes improve the learning process?

About $74 \%$ of the teachers claimed that face-to-face learning has improved the learning process during the pandemic. The informants added that some universities shifted towards the use of synchronous online courses since asynchronous online learning has negatively impacted the learning process. On the other hand, $26 \%$ of the teachers informed that the pandemic had affected the quality of teaching since online learning cannot replace face-to-face learning. They added that online learning could provide just supporting materials to improve education.

Third Question: Are teachers and students ready for online learning?

Most participants indicated that teachers found difficulties in the sudden shift since most of them do not master techno applications and platforms, mainly those who have a long experience in teaching following face-to-face mode. They added that old teachers have developed techno resistance towards these techno applications. How they can be encouraged and trained to use educational platforms and most of them represent generation gap or migrant era generations. Other problems are linked to students' low background in using educational 
platforms, their attitudes towards the use of social media in educational settings, the ministry policies to impose online learning without training teachers and students, lack of materials at the level of universities, net problems, and the social status of students.

Fourth Question: What are the teachers' and students' perceptions of using online learning during the pandemic?

About $86 \%$ of the teachers claimed that introducing online learning to education is essential. They added that education depends mainly on technology, and becomes an integral part of the former. However, face-to-face can never be replaced by online learning. As far as the perception of both teachers and students, $73 \%$ of the informants claimed that teachers' and students' perceptions were negative towards the sudden shift to online learning. They maintained that many factors lead to the negative perception, including lack of training and the ministry instructions to upload lectures within a short time. All these factors led to students' and teachers' technostress.

\section{Observation}

The researcher accessed mainly Moodle platform and the observation results are summarized as follows:

- About $91 \%$ of the lectures followed the asynchronous online mode in lecturing. This fact impacted students negatively since there was a lack of interaction and communication between teachers and students.

- Students' access to the platform was limited to small minority since they prefer to contact their teachers and upload lectures from networking sites like Facebook. They also choose to receive feedback for their assignments and homework through emails and not educational platforms.

- About $83 \%$ of the lectures posted on Moodle did not follow the guidelines of online lectures since teachers were trained neither on how to deliver an online course nor how to prepare an online assignment. This fact leads students to develop negative perceptions towards asynchronous online courses.

- The observation also revealed that the asynchronous online courses were posted as supplementary materials to support face-to-face sessions.

- The observation also showed that teachers and students still lack e-readiness. This is obvious in the number of viewers who accessed the platforms on the part of the students and the nature of the lectures posted by teachers.

\section{Discussion}

The findings of the study cast light on the teaching/learning situation in the Algerian context during the pandemic. The researcher found that Algerian universities shifted to online learning during the first months of 2020-2021. Most universities impose on teachers to post their lectures on platforms, mainly Moodle and Teams, during a short period. The analysis also 
indicated that students are not trained on how to use educational platforms. They are not familiar with online learning since they received courses through offline mode before the pandemic. The analysis also revealed that teachers found it a challenging task to move to online mode in a short time. They face difficulties since most of them resist change and prefer their teaching methodologies. Besides, they were trained just on how to use educational platforms not on how to prepare online courses and assignments. This finding answers the main research question piloting the study and confirms Dhawan's findings (2020) when he said that "the quality of elearning programs is a real challenge. There is no clear stipulation by the government in their educational policies about e-learning programs. This is a lack of standards for quality, quality control, development of e-sources, and e-content delivery"(p. 17).

The findings also indicated that online learning cannot replace offline mode due to many reasons including the interaction between teachers and students, students' e-readiness, and problems in the e-content for both the course and the assignment. The study also showed that the implementation of offline learning during 2020-2021 helped students in learning although the sessions were reduced to four or seven weeks per semester. The findings also demonstrated that online learning never substitutes offline learning and it becomes a necessity to support face-toface mode. What the ministry of higher education has planned in the Algerian context is to save the teaching-learning situation. This finding is similar to Liguori' and Winkler's research (2020) when they claimed that innovative solutions by institutions help just to deal with the situation during the pandemic. Hence, the introduction of both offline and online modes is a necessity to save the teaching/ learning situation in Algeria during the pandemic. Thus, it is not the time to explore how to adopt online learning methodologies or improve the quality of education during this period. This may answer the second research question "Does the offline mode affect teachers' and students' readiness for online learning?"

The analysis indicated that both teachers and students agree on introducing online learning and have developed awareness towards the use of tech tools in education; however, the sudden shift and the ministry policies to save the situation led to developing negative perceptions towards online learning. Universities need to train both teachers and students to develop their e readiness. Teachers' and students' negative perceptions are directed by many problems including teachers' resistance to change, lack of experience on how to use tech tools and deliver an econtent and assignment, and lack of tech materials. Other problems are linked to the technical problems and the social status of students. All these problems change students' perceptions towards the introduction of technology in education. This may answer the last research question "What are the teachers' and students' perceptions towards the online mode?"

\section{Conclusion}

The study aimed to shed light on the teaching/learning situation in the Algerian context during the pandemic. It is an original contribution that seeks to provide an in-depth look at the 
Arab World English Journal (AWEJ) 2nd Special Issue on Covid 19 Challenges January 2022

strategies and policies used by the Algerian Ministry of Higher Education to save the learning situation during the pandemic. The outbreak of the Covid-19 pandemic gave no time to policymakers, universities, and teachers to solve the situation, but it has taught us that we should not resist to change or instruct solutions without a plan. We have always to expect and plan for situations like the Covid pandemic. Besides, students need to learn that they should include critical thinking in real-life situations. They should also develop problem-solving skills which are important components of a good learner. Today, Algerian teachers are forced to introduce online learning and depend on tech tools to save the situation. It could be better if they were familiar with technology and its use before the pandemic. Now, we have to think about a plan to digitalize education in the post-pandemic era.

\section{About the Author \\ Dr Nadia GHOUNANE is a senior lecturer of English language and literature at Dr Moulay Tahar University of Saida, Algeria. Her field of interest includes ICT and teaching, CALL, MALL, teens' language and the use of social media, academic writing, and publishing. ORCiD: https://orcid.org/0000-0002-9491-7981}

\section{References}

Baczek, M. MD. et al. (2021). Students' Perception of Online Learning during the Covid-19 Pandemic. Medicine, 100(7), 1-6. doi: 10.1097/MD.0000000000024821

Benkhider, N., \& Kherbachi, S. (2020). The Influence of Remote Learning on Students' Learning Habits during Covid-19. Les Cahiers du Cread, 36(3), 425-448.

Chelghoum, A., \& Chelghoum, A. (2020). The Covid-19 Pandemic and Education: Big Changes ahead for Teaching in Algeria. ALTRALANG Journal, 2(2), 118-132.

Daniel, S. J. (2020). Education and the COVID-19 pandemic. Prospects, 1-6.

Dhawan, S. (2020). Online Learning: A Panacea in the Time of Covid-19 Crisis. Journal of Educational Technology Systems, 49(1), 5-22. doi: 10.1177/0047239520934018

Diswas, D., \& Dey, C. (2020). Offline vs. Online Education: Opportunities and Challenges in Indian Context. Conference paper.

Ghounane, N. (2020). Moodle or Social Networks: What Alternative Refuge is Appropriate to Algerian EFL Students to Learn during the Covid-19 pandemic. Arab World English Journal, 11(3), 21-41.

Ghounane, N. (2021). Facebook as a Learning Platform n Algeria during the Covid-19 Pandemic. Global Journal of Foreign Language Teaching, 11(2), 80-93.

Liguori E. W., Winkler C. (2020). From Offline to Online: Challenges and Opportunities for Entrepreneurship Education Following the COVID-19 Pandemic. Entrepreneurship Education and Pedagogy, 4(3), 10.1177/2515127420916738

Muthuprasad, T., Aiswarya, S., Aditya, K. S., \& Girish, K. J. (2021). Students' Perception and Preference for Online Education in India during Covid-19 Pandemic. Social Sciences and Humanities Open, 3, 1-11. 
Arab World English Journal (AWEJ) 2nd Special Issue on Covid 19 Challenges January 2022

Team Leverage Edu (2021). Online Classes vs. Offline Classes. Available at https://leverageedu.com/blog/online-classes-vs-offline-classes/ 